\title{
Assessment of Technical Difficulty and Complications of Urological Laparoscopic Operations According to "European Scoring System": 228 Cases
}

\author{
228 Olgu; Ürolojide Laparoskopik Ameliyatlarda Teknik Zorluk ile \\ Komplikasyonların Avrupa Skorlama Sistemi'ne Göre Değerlendirilmesi
}

\author{
Fuat Demirel, Fatih Yalçınkaya, Murat Çakan, Murat Topcuoğlu, Can Tuygun, Uğur Altuğ
}

Yıldırım Beyazıt Education and Research Hospital, Clinic of Urology, Ankara, Turkey

What's known on the subject? and What does the study add?

Assesstment of urological laparoscopic operations and complications as a standard way.

\begin{abstract}
Objective

Standardization is important for the assessment of technical difficulty and complications in laparoscopic urology surgery. In this study, our laparoscopic operations and complications were evaluated retrospectively by using the European Scoring System and Clavien classification system.
\end{abstract}

\section{Materials and Methods}

We evaluated a total of 228 laparoscopic urologiy procedures performed between 2002 and 2007. The first 114 cases were named as group 1 and the second 114 cases as group 2. Both of the groups were classified regarding technical difficulty according to the European Scoring System. Complications were divided into two groups: major and minor. Postoperative complications were evaluated by the Clavien classification system.

\section{Results}

The rate of difficult operations was $24.5 \%$ and $56.1 \%$ in group 1 and group 2, respectively. In group 1, major and total complications were more common in difficult operations than in easy operations ( $p=0.045$, $p=0.006)$. Minor complications were similar $(p=0.064)$. In group 2 , complication rates were similar for both difficult and easy operations. $(p=0.694, p=0.509, p=0.273)$. Complication rates per case was $0.21(0-3)$ in group 1 and $0.19(0-3)$ in group 2 and there was no significant difference between the two groups $(p=0.790)$. Postoperative complications were classified using the Clavien classification system. 17\% $(n=4 / 23)$ of 23 complication was grade $1,48 \%(n=11 / 23)$ was grade $2,26 \%(n=6 / 23)$ was grade $3 a, 9 \%(n=2 / 23)$ was grade $3 b$. There were no grade 4 and 5 complications. $3 \%$ of the cases were converted to open surgery and no statistically difference was found between the groups $(p=0.446)$.

\section{ÖZET}

Amaç

Ürolojik laparoskopik operasyonlarda teknik zorluk ve komplikasyonların değerlendirilmesinde standartizasyon önemlidir. Bu çalışmada laparoskopik operasyonlarımızı ve komplikasyonlanmızı Avrupa skorlama sistemi ve Clavien sistemi kullanılarak retrospektif olarak değerlendirildi.

Gereç ve Yöntem

2002-2007 yılları arasında yapılan 228 ürolojik laparoskopik prosedür değerlendirildi. İlk 114 olgu grup 1, ikinci 114 olgu ise grup 2 olarak adlandırıldı. Her iki grup teknik zorluk açısından Avrupa skorlama sistemine göre sınıflandırıldı. Karşılaşılan komplikasyonlar majör, ve minör olarak ayrıldı. Postoperatif komplikasyonlar ise Clavien sınıflaması ile değerlendirildi.

Bulgular

Grup I'de yapılan operasyonların $\% 24,5$ 'ini zor operasyonlar oluştururken, grup 2'de bu oran \%56,1 idi. Grup 1 olgularda, majör ve toplam komplikasyonlar zor ameliyatlarda, kolay ameliyatlara göre fazla bulundu $(p=0,045, p=0,006)$. Minör komplikasyonlar ise benzerdi $(p=0,064)$. Grup 2 'de ise tüm komplikasyonlar benzer bulundu $(p=0,694, p=0,509, p=0,273)$. Gruplar, olgu başına düşen komplikasyon oranlan açısından incelendiğinde grup l'de 0,21 (0-3), grup 2'de ise 0,19 (0-3) olarak bulundu ve gruplar arasında istatistiksel anlamda fark bulunmadı $(p=0,790)$. Aynca görülen postoperatif komplikasyonlar Clavien derecelendirme sistemine göre sınıflandırıldı. Yirmi üç komplikasyonun \%17'si $(n=4 / 23)$ grade $1, \% 48$ 'i $(n=I 1 / 23)$ grade 2, \%26'sı ( $n=6 / 23)$ grade $3 a, \% 9 ' u(n=2 / 23)$ grade $3 b$ iken, grade 4 ve grade 5 komplikasyon izlenmedi. Yüzde 3 olguda açık cerrahiye dönüldü ve gruplar arasında istatistiksel olarak fark bulunmadı $(p=0,446)$. 


\section{ABSTRACT}

\section{Conclusion}

We assume that the European Scoring System and the Clavien classification system are important in the assessment of difficulty of the cases and standardization of the analysis of postoperative complications.

\section{Key Words}

Laparoscopy, complication, European scoring system, Clavien system

\section{ÖZET}

\section{Sonuç}

Olguların zorluk derecelerinin değerlendirilebilmesinde ve postoperatif komplikasyonlarm analizinin standartizasyonun sağlanabilmesi için Avrupa skorlama sisteminin ve Clavien sınıflamasının önemli olduğunu düşünüyoruz.

\section{Anahtar Kelimeler}

Laparoskopi, komplikasyon, Avrupa skorlama sistemi, Clavien sistem

\section{Introduction}

Laparoscopic applications in urology has started with pelvic lymph node dissection in 1991 and had a wide area of usage increasingly in the following years (1). The evaluation of the laparoscopic surgical approaches for the degree of difficulty has been done via the European Scoring System (ESS) (2). Thus, the standardization of laparoscopic surgical procedures and the objective assessment of complications were hoped to be provided. Although they are less invasive applications, it must be kept in mind that laparoscopic surgeries are major surgical applications which may have very serious complications (3). Postoperative complications have been categorized according to the length of hospitalization period until now (4). The median duration of hospital stay is not used for evaluation nowadays because it varies between different clinics and, instead of that, evaluation is being done objectively by a postoperative complication scoring system which was published in 1992 and validated in 2004 by Clavien et al. $(5,6)$. In this article, 228 urological procedures performed in our clinic were assessed using the ESS, while the complications were classified according to the Clavien classification system and the results were evaluated retrospectively.

\section{Materials and Methods}

A total of 228 laparoscopic urology procedures performed in our clinic between 2002 and 2007 were evaluated. Group 1 included 114 cases operated between January 2002 and June 2005, and group 2 included 114 cases operated between July 2005 and December 2007. Both groups were classified according to the ESS (2). By using this classification system, easy and mild difficult surgical procedures were all named as easy operations (EO); whereas the pretty difficult, difficult and highly difficult operations were named as difficult operations (D0). Complications were classified as major and minor. While the major complications were accepted as complications that needed significant additional treatment and hospitalization more than 2 days (Clavien grade 3-5); minor complications were considered as ones that needed minimal additional treatment and hospitalization not more than 2 days (Clavien grade 1-2) (7). Postoperative operations were also classified by the Clavien classification system. This classification included 7 groups; grade 1: No need for additional treatment; grade 2: Need for medical treatment including blood transfusion and total parenteral nutrition; grade 3: Need for endoscopic surgery and radiological intervention (grade $3 a$ : no need for general anaesthesia, grade $3 b$ : need for general anaesthesia); grade 4 : need for intensive care-life threatening (grade 4a: single organ disorder including hemodialysis, grade $4 b$ : multi-organ disorder); grade 5 : death due to the complications (6).

Analysis of data was performed via SPSS 11.5 program. Descriptive statistics were expressed as mean \pm standard deviation (minimummaximum); for continuous variables and nominal properties were expressed as number of cases and as percentage (\%). The significance of the difference between the groups due to the mean ages were assessed by student's t-test; operation difficulty score and the significance of the difference due to complication number per each case were evaluated via the Mann-Whitney $U$ test. Whether there was a statistically significant difference or not between the groups considering nominal features were assessed by using chi-square test or Fisher's exact probability test. A p value of less than 0.05 was considered statistically significant.

\section{Results}

The mean age of the group 1 and the group 2 was $42.2 \pm 22.95$ years (1-82) and $41.8 \pm 21.72$ years (2-78), respectively. There was no statistically difference in mean age and gender between the groups ( $p=0.882, p=0.412$, respectively) (Table 1 ). A statistically significant difference was detected in ESS score range and mean score per unit case between the groups $(p<0.001)$ (Table 1). Details of the ESS distribution of group 1 and group 2 are demonstrated in Table 2 . While $24.5 \%$ of the operations in group 1 were DO $(n=28 / 114)$, this rate was $56.1 \%$ ( $n=64 / 114$ ) in group 2 (Figure 1). Classification of major and minor complications are shown in Table 3. According to detailed analysis of group 1 and group 2 regarding complications; when the number of cases with major and total complications were investigated from the aspect of EO and DO, the number of cases with D0 was found to be significantly larger in group $1(p=0.045$,

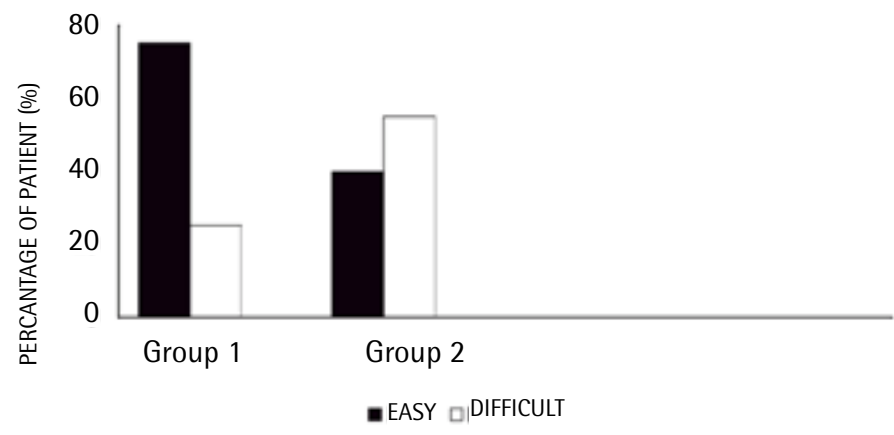

Figure 1. Distribution of operations according to difficulty level 
$p=0.006$, respectively). However, minor complications in the same group were similar regarding DO and EO ( $p=0.064)$. When group 2 was investigated considering DO and EO, the number of cases having major, minor and total complications were similar ( $p=0.694, p=0.509$, $p=0.273$, respectively) (Table 4 ). In group 2, major complications were detected to decrease compared to group 1; from $10.7 \%(n=3 / 28)$ to $6.3 \%(n=4 / 64)$, however, this result was not found to be statistically significant ( $p=0.431$ ) (Table 4$)$. In 30 cases from each group, a total of 46 complications were seen. When the two groups were compared for the total number of complications, 24 complications in group 1 and 22 complications in group 2 were recorded. The rate of complications per unit case was found to be $0.21(0-3)$ in group 1 whereas it was 0.19 (0-3) in group 2, and no statistically significant difference

Table 1. The demographics of groups and distribution of operations according to difficulty level

\begin{tabular}{|l|l|l|l|}
\hline & Group 1 $(n=114)$ & Group 2 $(n=114)$ & $p$ \\
\hline Age & $42.2 \pm 22.95(1-82)$ & $41.8 \pm 21.72(2-78)$ & 0.882 \\
\hline Gender & & & 0.412 \\
\hline Male & $74(64.9 \%)$ & $68(59.6 \%)$ & \\
\hline Female & $40(35.1 \%)$ & $46(40.4 \%)$ & \\
\hline Total score & 771 & 1039 & \\
\hline Score per case & $8.8 \pm 14.33(3-13)$ & $11.8 \pm 12.55(3-19)$ & $<0.001$ \\
\hline Difficulty level & & & $<0.001$ \\
\hline Easy & $86(75.4 \%)$ & $50(43.9 \%)$ & \\
\hline Difficult & $28(24.6 \%)$ & $64(56.1 \%)$ & \\
\hline
\end{tabular}

was detected between the groups $(p=0.790)$. The postoperative complications were classified according to the Clavien scoring system. $17 \%$ of 23 complications were $(n=4 / 23)$ grade $1,48 \%(n=11 / 23)$ were grade $2,26 \%(n=6 / 23)$ were grade $3 a$, and $9 \%(n=2 / 23)$ were grade $3 \mathrm{~b}$, while no complication was seen in grade 4 and grade 5 (Table $5)$. Open surgery was essential in $3 \%$ of cases $(n=7 / 228)$. Five (5) of these cases were in group 1, two (2) cases were in group 2. There was no statistically significant difference between the groups $(p=0.446)$. However, it was important that although DO rate in group 2 was high, the rate of open surgery was decreased.

\section{Discussion}

Laparoscopic surgery in urology has been very popular in the past 15 years $(8,9,10,11)$. Nowadays, it is routinely being applied in many health centers in reconstructive and ablative surgery cases $(12,13)$. As a result of long-term experience, various studies comparing laparoscopic surgery to open surgery have been performed and it was suggested that laparoscopic surgery is preferable $(14,15)$. Meanwhile, studies comparing the complications of laparoscopic surgery and open surgery defined no difference between the complication rates $(8,16)$. Until the late 1990 s, only complications in specific interventions and low number of cases of complication were reported $(11,13,16,17)$. In recent years, complications with large number of cases and complications of various laparoscopic procedures have been investigated $(7,18,19,20)$. The investigations reporting complication rates in a wide range from $4.4 \%$ to $19 \%$ have been recently published $(10,15,17,21)$. For example, in two different case series, one with 1769 cases and other with 2966 cases have

Table 2. Classification of cases according to European scoring system and scores

\begin{tabular}{|c|c|c|c|c|}
\hline Easy Operation & & & Group 1 & Group 2 \\
\hline Easy & Cryptorchidism (diagnostic) & 4 & 5 & \\
\hline Easy & Varicocele & 2 & - & \\
\hline Easy & Resection of cortical renal cyst & 55 & 20 & \\
\hline Slightly difficult & $\begin{array}{l}\text { Cryptorchidism } \\
\text { (therapeutic) }\end{array}$ & 19 & 14 & \\
\hline Slightly difficult & Resection of parapelvic renal cyst & 6 & 8 & \\
\hline \multirow[t]{2}{*}{ Slightly difficult } & Ureterolithotomy & - & 3 & \\
\hline & & Subtotal (n) & 86 & 50 \\
\hline Difficult operations & Fairly difficult & Adrenalectomy & 2 & 4 \\
\hline Fairly difficult & Nephrectomy (benign) & 19 & 37 & \\
\hline Difficult & Nephroureterectomy & - & 4 & \\
\hline Difficult & Pyeloplasty (resection -suture) & 1 & 3 & \\
\hline Difficult & Radical nephrectomy (T1) & 6 & 8 & \\
\hline Very difficult & Partial nephrectomy & - & 1 & \\
\hline Extremely difficult & Lumboaortic lymphadenectomy (post chemotherapy) & - & 1 & \\
\hline Extremely difficult & Radical prostatectomy & - & 5 & \\
\hline \multirow[t]{3}{*}{ Extremely difficult } & Radical cystectomy* & - & 1 & \\
\hline & Subtotal (n) & 28 & 64 & \\
\hline & Total Numbers (n) & $n=114$ & $n=114$ & \\
\hline
\end{tabular}


reported complication rates as low as $1.9 \%$ and $0.46 \%$, respectively, however in these series, procedures were particularly easy descriptive interventions $(22,23)$.

By using the ESS, it is possible to evaluate the relationship of laparoscopic surgeries with various difficulty degrees and the complications more comprehensively. For example in a study of 2407 cases with 63\% easy and mild difficult cases, the total complication rate was reported as $4.4 \%$ (24). Similarly in a study of 350 cases with $67 \%$ having particularly easier operations like pelvic lymph node dissection, urinary bladder neck suspension, and varicocelectomy, the complication rate was found to be $5.4 \%$ (25). Whereas Colombo et al. reported complications rate of $12.5 \%$ in a study of 1867 cases composed of difficult, very difficult and highly difficult procedures (26). Similarly, Parson et al. found a complications rate of $13.2 \%$ in a study of 894 cases with $73 \%$ difficult and very difficult operations (18). If we had reported the complication rate in our cases without classifying according to ESS, we would face a complication rate of $13 \%$. However, in our cases, complication rate for EO and DO was $8 \%(n=11 / 136)$, and $20 \%(n=19 / 92)$, respectively. There are various opinions and results about complication rates as the experience in laparoscopic surgery increases $(18,27)$. Vallancien et al. suggested that at least 50 difficult cases must be operated to gain the sufficient laparoscopic proficiency, as a conclusion of a study investigating

Table 3. Classification of major and minor complications

\begin{tabular}{|l|}
\hline Major Complications \\
\hline Vascular injury \\
\hline Adjacent organ injury \\
\hline Testicular ischemia \\
\hline Extended lymph drainage \\
\hline Minor Complications \\
\hline Ileus \\
\hline Neuromuscular pain \\
\hline Wound infection \\
\hline Port hernia \\
\hline Arhythmia \\
\hline Hypercapnia \\
\hline
\end{tabular}

laparoscopic urological complications in 1311 cases and reported that a complication rate of $13.3 \%$ in first 100 cases has decreased to a lower degree of 3.6\% in latter cases (19). Similarly in a study of 2775 cases, it has been reported that complication cases decreased from $22.1 \%$ to $17 \%$ despite increasing difficulty (7). Whereas Colombo et al. and Parson et al. found no statistically significant, decrease in complication rates $(18,26)$. In our study, the mean difficulty point per unit case according to the ESS was found to be $8.8(n=771 / 114)$ in group 1 , and $11.8(n=1039 / 114)$ in group 2 . This result was statistically significant $(p<0.001)$. Despite the larger number of very difficult operations in group 2, total complication rates were similar between the groups $(12.3 \%, 14 \%)(p=0.695)$. Although major complication rates in group 1 and group 2 for DO values decreased from 10.7\% $(n=3 / 28)$ to $6.3 \%(n=4 / 64)$, this decrease was not found to be statistically significant ( $p=0.431)$ (Table 4).

The Clavien classification system that was validated in 2004 is recently being used to describe the serious complications and to standardization of evaluation for postoperative complications $(6,20,28,29)$. Exclusion of the intra-operative complications has been reported to be the disadvantage of this classification (30). Perpomb et al. have suggested modification of the Clavien system to include intraoperative complications (7). Teber et al. have found that the complication rate for grade $3 a$ was higher as $1.8 \%(n=13 / 692)(20)$. Grade $3 a$ and higher postoperative complications were found as 3.5\% $(n=8 / 228)$ in our study. The port sites, including fascia were closed surgically. Nevertheless, port hernia cases were repaired with local anaesthesia. In our study, there was no death due to surgery.

Vessel injury is reported to be the most common complication during peroperative dissection $(25,31,32)$. Teber et al. reported vessel injury rate as $1.7 \%$ and organ injury rate as $0.25 \%$ (20). In our study, vessel injury rate was $3.5 \%(n=8 / 228)$, and organ injury rate was $0.87 \%$ $(n=2 / 228)$. In a study performed in 2007, converting to open surgery during laparoscopic urological procedures was considered to be a major complication (20). In some studies, need for open surgery was not regarded as a complication, thus, it was not included in complication group $(26,33)$. Also in our study, converting to open surgery was not considered a complication. Totally, 7 patients $(3 \%$; $n=7 / 228$ ) have undergone open surgery. Four (4) of these 7 cases were in group 1, and 3 in group 2. The reasons for open surgery were

Table 4. Difficulty level of operations and rates of complications according to European scoring system

\begin{tabular}{|c|c|c|c|c|c|c|c|c|}
\hline & $\begin{array}{l}\text { Easy operations } \\
\text { group }\end{array}$ & $\begin{array}{l}\text { Difficult operations } \\
\text { group }\end{array}$ & $\mathrm{p}^{\mathrm{a}}$ & $p^{b}$ & & & & \\
\hline Group1 $(n=86)$ & Group $2(n=50)$ & $p^{c}$ & $\begin{array}{l}\text { Group } 1 \\
(n=28)\end{array}$ & $\begin{array}{l}\text { Group } 2 \\
(n=64)\end{array}$ & $p^{d}$ & $\begin{array}{l}\text { Easy } \\
\text { Difficult }\end{array}$ & $\begin{array}{l}\text { Easy } \\
\text { Difficult }\end{array}$ & \\
\hline $\begin{array}{l}\text { Major } \\
\text { complication }\end{array}$ & $1(1.2 \%)$ & $2(4.0 \%)$ & 0.554 & $3(10.7 \%)$ & $4(6.3 \%)$ & 0.431 & 0.045 & 0.694 \\
\hline $\begin{array}{l}\text { Minor } \\
\text { complication }\end{array}$ & $5(5.8 \%)$ & $3(6.0 \%)$ & 1.000 & $5(17.9 \%)$ & 7 (10.9\%) & 0.502 & 0.064 & 0.509 \\
\hline $\begin{array}{l}\text { Total } \\
\text { complication }\end{array}$ & $6(7.0 \%)$ & $5(10.0 \%)$ & 0.532 & $8(28.6 \%)$ & $11(17.2 \%)$ & 0.215 & 0.006 & 0.273 \\
\hline \multicolumn{9}{|c|}{$\begin{array}{l}\text { a- Comparison of complications between easy and difficult operations for group } 1 \\
\text { - Comparison of complications between easy and difficult operations for group } 2 \\
\text { c- Comparison of complications between group } 1 \text { and group } 2 \text { for easy operations group } \\
\text { d- Comparison of complications between group } 1 \text { and group } 2 \text { for difficult operations group }\end{array}$} \\
\hline
\end{tabular}


Table 5. Classification of post operative complications according to Clavien grading system

\begin{tabular}{|l|l|}
\hline Grade 1 & Complication number (n) \\
\hline Emphysema & 3 \\
\hline Temporary hematuria & 1 \\
\hline Grade 1 & \\
\hline Extended lymph drainage & 1 \\
\hline Neuromuscular pain & 3 \\
\hline lleus & 6 \\
\hline Wound infection & 1 \\
\hline Grade 3A & \\
\hline Colon fistula & 1 \\
\hline Port hernia & 5 \\
\hline Grade 3B & \\
\hline Renal fistula & 1 \\
\hline Testicular ischemia & 1 \\
\hline Grade 4-5 & \\
\hline Multi Organ Disfunction & 0 \\
\hline Total Number (n) & 23 \\
\hline
\end{tabular}

vessel injury (vena cava, renal vein) in 2 cases, colon perforation in 1 case, and prolongation of operation time due to technical and experience deficiency in 4 cases. Colon injury was repaired by peroperative open surgery. Colonic fistula in postoperative period healed spontaneously following short-term slow drainage. There are studies reporting open surgery rates of $0.09 \%, 1.4 \%$ and $2.7 \%$ in the literature $(7,20,26)$. Several studies have reported that laparoscopic intervention was applied for many complications occurring during the operation (34). These results are supported by many studies with the rates of converting to open surgery decreasing from $28 \%$ to $0 \%$ values $(24,34)$. In our cases, 8 cases had serious vessel injury and 6 of them were solved by laparoscopic restoration.

Laparoscopic surgery has been recommended for many urological procedures nowadays. Although it is less invasive, the fact that it is still a major surgery should be kept in mind. In many centers, although highly difficult cases are being operated, it was reported that the complication rates are decreasing and successful results are being obtained as the experience is increasing. We also did not detect any increase in complication rates because of the increase in our surgical experience. We suggest that the European Scoring System and Clavien classification are important for the evaluation of difficulty degrees of cases and to provide standardization for accurate analysis of postoperative complications.

Ethics Committee Approval: We dont think it necessary for Ethics Committee approval and informed consent by reason of our study is a retrospective evaluation.

Concept: Fuat Demirel

Design: Murat Topcuoğlu

Data Collection or Processing: Murat Topcuoğlu

Analysis or Interpretation: Fuat Demirel

Literature Search: Murat Topcuoğlu, Fuat Demirel

Writing: Fuat Demirel, Murat Topcuoğlu
Peer-review: Externally peer-reviewed.

Conflict of Interest: No conflict of interest was declared by the authors.

Financial Disclosure: The authors declared that this study has received no financial support.

\section{References}

1. Schuessler WW, Vancaillie TG, Reich H, Griffith DP. Transperitoneal endosurgical lymphadenectomy in patients with localized prostate cancer. J Urol 1991;145:988-991.

2. Guillonneau B, Abbou CC, Doublet JD, Gaston R, Janetschek G, Mandressi A, Rassweiler JJ, Vallancien G. Proposal for a 'European Scoring System for laporoscopic operations in Urology. Eur Urol 2001;40:2-7.

3. Soulie M, Salomon L, Seguin P, Mervant C, Mouly P, Hoznek A, Antiphon P, Plante P, Abbou CC. Multi-institutional study of complications in 1085 laporoscopic urologic procedures. Urology 2001;58:899-903.

4. Baniel J, Foster RS, Rowland RG, Bihrle R, Donohue JP. Complications of primary retroperitoneal lymph node dissection. J Urol 1994;152:424.

5. Clavien PA, Sanabria JR, Strasberg SM. Proposed classification of complications of surgery with examples of utility in cholecystectomy. Surgery 1992;111:518-526.

6. Dindo D, Demartines N, Clavien PA. Classification of surgical complications: A new proposal with evaluation in a cohort of 6336 patients and results of a survey. Ann Surg 2004;240:205-213.

7. Permpongkosol S, Link RE, Su LM, Romero FR, Bagga HS, Pavlovich CP, Jarrett TW, Kavoussi LR. Complications of 2775 Urological laporoscopic procedures: 1993 to 2005. J Urol 2007;177:580-585.

8. Abbou CC, Cicco A, Gasman D, Hoznek A, Antiphon P, Chopin DK, Salomon L. Retroperitoneal laparoscopic versus open radical nephrectomy. J Urol 1999;161:1776-1780.

9. Abbou CC, Salomon L, Hoznek A, Antiphon P, Cicco A, Saint F, Alame W, Bellot J, Chopin DK. Laparoscopic radical prostatectomy:preliminary results. Urology 2000;55:630-634.

10. Guillonneau B, Vallancien G. Laparoscopic radical prostatectomy: The Montsouris experience. J Urol 2000;163:418-422.

11. Rassweiler JJ, Seman O, Frede T Retroperitonescopy: experience with first cases. J Urol 1998;160:1265-1269.

12. Gill IS, Clayman RV, McDougal EM. Advances in urological laparoscopy. J Urol 1995;154:1275-1294.

13. Gill IS, Clayman RV, Albala DM, Aso Y, Chiu AW, Das S, Donovan JF, Fuchs GJ, Gaur DD, Go H, Gomella LG, Grune MT, Harewood LM, Janetschek G, Knapp PM, McDougall EM, Nakada SY, Preminger GM, Puppo P, Rassweiler JJ, Royce PL, Thomas R, Urban DA, Winfield HN. Retroperitoneal and pelvic extraperitoneal laparoscopy: an international perspective. Urology 1998;52:566-571.

14. Gill IS, Matin SF, Desai MM, Kaouk JH, Steinberg A, Mascha E, Thornton J, Sherief MH, Strzempkowski B, Novick AC. Comparative analysis laparoscopic versus open partial nephrectomy for renal tumors in 200 patients. J Urol 2003;170:64-68.

15. Meraney AM, Gill IS. Financial analysis of open versus laparoscopic radical nephrectomy and nephroureterectomy. J Urol 2002;167:1757-1762.

16. Ono $Y$, Kinukawa $T$, Hattori $R$, Yamada $S$, Nishiyama N, Mizutani $K_{1}$ Ohshima S. Laparoscopic radical nephrectomy for renal cell carcinoma: a five-year experience. Urology 1999;53:280-286.

17. Gagner M, Pomp A, Heniford T, Pharand D, Lacroix A. Laparoscopic adrenelectomy : lessons learned from 100 consecutive procedures. Ann Surg 1997;226:238-247.

18. Persons K, Varkarakis I, Rha KH, Jarrett TW, Pinto PA, Kavoussi LR. Complications of abdominal urologic laparoscopy: Longitudinal five-year analysis. Urol 2004;63:27-32. 
19. Vallancien G, Cathelineau X, Baumert H. Complications of transperitoneal laparoscopic surgery in urology: Review of 1311 procedures at a single center. J Urol 2002;168:23-26.

20. D Teber, A Tefekli, S Eskicorapci, AS Gözem, Svetlana Bujosevic, Marto Sugiono, Christian Stock, Jens J. Rassweiler. Retroperitoneoscopy: A versatile Access for many urologic indications. Eur Urol Suppl 2006;5:975982.

21. Rassweiler J, Fornara $P$, Weber $M$, Janetschek $G$, Fahlenkamp $D$, Henkel $T$, Beer M, Stackl W, Boeckmann W, Recker F, Lampel A, Fischer C, Humke U, Miller K. Laparoscopic nephrectomy: the experience of the Laparoscopy Working Group of the German Urologic Association. J Urol 1998;160:1821.

22. Leng J, Lang J, Huang R. Complications in laparoscopic gynecologic surgery. Zhonghua Fu Chan Ke Za Zhi 2001;36:146-150.

23. Chapron C, Pierre F, Querleu D, Dubuisson JB. Complications of laparoscopy in gynecology. Gynecol Obstet Fertil 2001;29: 605-612.

24. Fahlenkamp D, Rassweiler J, Fornara P, Frede T, Loening SA. Complications of laparoscopic procedures in urology: Experience with 2407 procedures at 4 German centers. J Urol 1999;162:765-771.

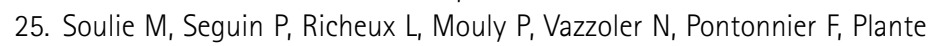
P. Urological complications of laparoscopic surgery: experience with 350 procedures at a single center. J Urol 2001;165:1960-1963.

26. Colombo JR, Haber GP, Jelovsek E. Complications of laparoscopic surgery for urological cancer: A single institution analys.. J Urol 2007;178:786791.

27. Cadeddu JA, Wolfe JSJ, Nakada S, Chen R, Shalhav A, Bishoff JT, Hamilton B, Schulam PG, Dunn M, Hoenig D, Fabrizio M, Hedican S, Averch TD.
Complications of laparoscopic procedures after concentrated training in urological laparoscopy. J Urol 2001;166:2109-2111.

28. Gonzalgo ML, Pavlovich $C P$, Trock BJ, Link RE, Sullivan $W$, Su LM Classfication and trends of perioperatif morbidities following laparoscopic radical prostatectomy. J Urol 2005; 174: 135.

29. Guillonneau B, Rozet F, Cathelineau X, Lay F, Barret E, Doublet JD, Baumert $H$, Vallancien G. Perioperatif complications of laparoscopic radical prostatectomy: The Montsouris 3-year experience. J Urol 2002;167:5156.

30. Stolzenburg JU, Rabenalt $R$, Do $M$, Lee $B$, Truss MC, Schwaibold $H_{\text {, }}$ Burchardt $M$, Jonas $U$, Liatsikos EN. Categorisation of complications of endoscopic extraperitoneal and laparoscopic transperitoneal radical prostatectomy. World J Urol 2006;24:88-93.

31. Siqueira $T M, K u o J R L$, Gardner $T A$, Paterson $R F$, Stevens $L H$, Lingeman JE, Koch MO, Shalhav AL. Major complications in 213 laparoscopic nephrectomy cases: The Indianapolis experience. J Urol 2002;168:13611365.

32. Gill IS, Kavoussi LR, Clayman RV, Ehrlich R, Evans R, Fuchs G, Gersham A, Hulbert JC, McDougall EM, Rosenthal T. Complications of laparoscopic nephrectomy in 185 patients: multi-institutional review. J Urol 1995; 154:479-483.

33. Matthew D, Shuford MD, Elspeth M, LaFleur BJ, Smith JA Jr, Cookson MS. Complications of contemporary radical nephrectomy: comparison of open vs. laparoscopic approach. Urol Oncol 2004;22:121-126.

34. Desai M, Strzempkowski radical nephrectomy B, Matin SF. Prospective randomised comparison of transperitoneal versus retroperitoneal laparoscopic. J urol 2005;173:38-41. 